\title{
Healthcare resource utilization and costs associated with anogenital warts in Morocco
}

\author{
Myriam Berrada ${ }^{1 *}$, Ryan Holl${ }^{2}$, Tidiane Ndao ${ }^{1}$, Goran Benčina ${ }^{3}$, Siham Dikhaye ${ }^{4,5}$, Abdelilah Melhouf ${ }^{6}$, \\ Soumiya Chiheb ${ }^{7}$ and Khalid Guelzim ${ }^{8}$
}

\begin{abstract}
Background: Human papillomavirus (HPV), primarily genotypes 6 and 11, cause the majority of cases of anogenital warts (AGW). Although benign, AGW are associated with a substantial economic and psychosocial burden. Several vaccines have been developed to prevent HPV. The objective of this study was to describe the epidemiology and healthcare resource utilization of AGW in Morocco, as well as the associated costs of treatment from the public healthcare perspective.
\end{abstract}

Methods: This was a descriptive analysis of questionnaire data obtained via a Delphi panel. The panel consisted of 9 physicians practicing in public hospitals in Morocco (4 dermatologists and 5 obstetricians/gynecologists). The questionnaire collected data on physician and practice characteristics, diagnostic tests and procedures, treatments, and follow-up (including recurrence) of patients with AGW. Questionnaire items on which $\geq 70 \%$ of respondents agreed were considered as having consensus. Costs associated with diagnosis, treatment, and follow-up were calculated in Moroccan dirham (MAD) and converted to euros $(€)$ based on official national price lists for public hospitals and the HCRU estimates from the questionnaire.

Results: The physician-estimated prevalence of AGW in Morocco was 1.6\%-2.6\% in women and 2.0\%-5.3\% in men. A mean (median) of 6.4 (4) patients per month per physician sought medical attention for AGW. Simple observation was the most common diagnostic method for AGW in both men and women, and excision was the most prescribed therapy (75\%), requiring a mean of 2 visits. Recurrence occurred in approximately $27 \%$ of patients. The cost per case of managing AGW, including recurrence, was estimated at 2182-2872 MAD (€207-272) for women and 2170-2450 MAD (€206-233) for men. The total annual cost of medical consultations for AGW in Morocco ranged from 3,271,877 MAD to 4,253,703 MAD (€310,828-404,102).

Conclusions: Expert consensus indicates that AGW represent a significant burden to the Moroccan public healthcare system. These data can inform policy makers regarding this vaccine-preventable disease.

Keywords: Anogenital warts, Genital warts, Condyloma acuminatum, Papillomavirus infections, Epidemiology, North Africa, Health care utilization, Health care costs

\section{Background}

Human papillomavirus (HPV) is well known as a causative agent of anogenital cancers [1], and several vaccines have been developed to prevent cancers associated with

*Correspondence: myriam.berrada@merck.com

${ }^{1}$ MSD, Casablanca, Morocco

Full list of author information is available at the end of the article multiple oncogenic HPV genotypes [2]. However, HPV also causes the majority of cases of anogenital warts (AGW) [1], which are benign proliferative lesions found on the epithelium of the genitalia, anus, or perianal area. AGWs, also called condyloma acuminata, are among the most common sexually transmitted viral infection in the world for both men and women. More than $90 \%$ of cases of AGWs are caused by low-risk HPV types 6 or 11 while original author(s) and the source, provide a link to the Creative Commons licence, and indicate if changes were made. The images or other third party material in this article are included in the article's Creative Commons licence, unless indicated otherwise in a credit line to the material. If material is not included in the article's Creative Commons licence and your intended use is not permitted by statutory regulation or exceeds the permitted use, you will need to obtain permission directly from the copyright holder. To view a copy of this licence, visit http://creativecommons.org/licenses/by/4.0/. The Creative Commons Public Domain Dedication waiver (http://creativeco mmons.org/publicdomain/zero/1.0/) applies to the data made available in this article, unless otherwise stated in a credit line to the data. 
$10 \%$ of cases are associated with high-risk HPVs [3]. Furthermore, HPV appears to play a strong role in the development of anogenital cancers and high-risk HPV types 16 and 18 can be detected in more than $70 \%$ of cervical cancers $[4,5]$. Although benign, AGW are associated with a substantial economic and psychosocial burden [6, 7]. Both the quadrivalent and the nonavalent HPV vaccines target HPV 6 and 11, providing protection against the cause of $90 \%$ of AGW [2].

Based on a systematic review of studies from Europe, the Americas, East Asia, and Australia, AGW are present in $0.2 \%$ to $5.0 \%$ of the general population (both males and females), but epidemiological data from Africa are limited [8]. A review of studies from sub-Saharan Africa found only two reports of the prevalence of AGW through the year 2012 [9]. AGW were present in $1.9 \%$ of men and $0.4 \%$ of women attending a sexually transmitted infection clinic in Harare, Zimbabwe, in 1980 [10]; and among female sex workers in Burkina Faso in 2003-2006, AGW were present in $1.6 \%$ of HIV-negative women and $7.0 \%$ of HIV-positive women [11]. More recent studies have reported prevalence values for AGW of $1 \%$ in HIV-negative women in Nigeria [12] and $2 \%$ in women of reproductive age in Swaziland [13]. However, epidemiological data from Northern Africa are lacking.

Morocco is one of the few African countries to have plans for an HPV vaccination program and to offer the vaccine in the private sector $[14,15]$. The high rates of cervical cancer and cervical cancer-related mortality in Morocco are well documented [16], but less is known about the prevalence and burden of AGW in this North African country. The main objective of this study was to characterize the epidemiology and healthcare resource utilization of patients with AGW in Morocco and then calculate the associated costs of treatment from the public healthcare perspective. This information will provide a basis for evaluating the benefits of HPV vaccination beyond cancer prevention.

\section{Methods Study design}

This was a descriptive study utilizing a Delphi panel as a means to build consensus on the patterns of management of AGW in Morocco. The Delphi technique synthesizes the opinions of a panel of experts via multiple rounds of questionnaires. In the current study, two rounds of individual and anonymous questionnaires were administered to each panel member in December of 2019, and consensus was defined as agreement among $\geq 70 \%$ of the panelists [17]. After round 1, a report was written to summarize areas of consensus and non-consensus, and a second questionnaire was administered to further query the areas of non-consensus. In this second round, panel members were asked to review the outcome of the first round and either agree with the reported outcome or recommend and justify changes. Round 2 was followed by a group discussion (via teleconference or e-mail) in order to reach consensus on any outstanding questionnaire items. For patterns of diagnosis, treatment, and follow-up that attained consensus, the associated costs were calculated. The study protocol was approved by a national ethics committee, the Comité D'Ethique pour la Recherche Biomédicale (CERB).

\section{Study sample}

Ten experts in the field of AGW were recruited, specifically dermatologists and obstetrician/gynecologists. In order to be considered for participation in the panel, subject matter experts had to (1) be based in Morocco and known as a subject matter expert in the management of AGW, (2) have an active medical practice where patients with AGW are treated, and (3) work at least part-time in the public sector. A signed confidentiality disclosure agreement was required for participation. Individuals were excluded from participation if they (1) might be involved in the decision to include HPV vaccination in the National Immunization Program, (2) only worked in private medical offices and/or private clinics, or (3) failed to sign the confidentiality disclosure agreement for the study.

\section{Study questionnaire}

The full questionnaire from round 1 is shown in the Appendix. It collected information in 4 main sections: (1) information about the panelist (e.g., sex, age, institution, medical field, years in practice); (2) clinical practice characteristics (number of patients seen per month, gender and age of patients, prevalence of AGW); (3) institutionlevel data on diagnosis and treatment of AGW, availability of guidelines, and healthcare resource utilization (HCRU; i.e., hospitalization); and (4) outcomes of AGW management (side effects, complications, referrals to other specialties, follow-up, and recurrences). Questions generally took one of two forms, asking either for a number (e.g., percentage of patients, duration of treatment in years, estimate of prevalence, etc.) or for a categorical designation (e.g., yes/no; or never, sometimes, regularly, or always).

\section{Statistical analysis}

One panelist cancelled his participation before the first questionnaire was administered, leaving a total study sample of 9. All questionnaires of the panelists who met the inclusion and exclusion criteria and who agreed to participate in the Delphi panel were analyzed and constitute the full analysis data set. The analysis of each round 
of questionnaires was performed after the last panelist had completed the scheduled assessments and the database had been cleaned and locked. All analyses were descriptive and were performed by a third-party vendor using SAS $^{\circledR}$ software (SAS Institute, North Carolina, USA).

Responses measured as continuous variables were summarized by the number of missing and non-missing observations, as well as the mean, standard deviation, median, minimum, interquartile range (IQR), and maximum values. Due to the small sample size, the results for continuous variables are generally reported in this paper as the median and IQR, with exceptions indicated in the tables or text. Categorical variables were described by the number and the percentage of answers in each category, as well as the number of missing data points, if any; the percentages are generally presented in the text. Percentages are based on non-missing observations; panelists had the freedom to answer or not answer specific questions, and the missing data were not imputed. For categorical data, consensus was defined by agreement of $\geq 70 \%$ of the panelists on an item or when the number of respondents answering (always + regularly) or (never + sometimes) was $\geq 70 \%$.

For questions related to diagnosis, treatment, followup, and recurrence, costs were calculated in Moroccan dirham (MAD) for items reaching consensus. The base cost of each diagnostic method and of treatment, follow-up, and recurrence was obtained from the official national nomenclature lists [18-20] as applied to public healthcare settings. The conversion of base costs to total costs is explained in Additional file 1: Table S1. In brief, the total cost was the sum of (1) the cost of all diagnostic tests given regularly or always, (2) the final cost of the diagnostic method, (3) the cost of first-line treatment, and (4) the cost of follow-up via simple observation. For cost analyses, recurrence was defined as another round of treatment and follow-up. Costs are presented in MAD and in euros $(€)$ using the exchange rate of 1 $\mathrm{MAD}=0.095 €$.

The annual national cost of AGW management was also calculated based on the estimated annual number of patients and unit costs for healthcare resources. Taking into account the main Moroccan public hospitals with dermatological and gynecological departments where patients are treated for AGW (26 departments including the 9 departments represented by panelists), and using the panelists' estimate of a mean of 6.4 patients seen per month, this represents 1997 medical consultations for AGW per year. The minimum and maximum costs per consultation, adjusted by the cost of recurrence at a frequency of $27 \%$, were calculated separately for men and women and then multiplied by 1997 to obtain the total, population level cost for men and women. These values were then summed via a weighted average $(27 \%$ men, $73 \%$ women) to give the total overall estimated cost of management of AGW in the Moroccan public healthcare sector.

\section{Results}

\section{Physician and practice characteristics}

Nine physicians participated in the Delphi panel (Table 1). Six were males, 5 were obstetricians/gynecologists, and the median age was 50 years. The median practice duration was 20 years, and panelists reported seeing a median of 4 patients with AGW per month (mean 6.4). Among patients with AGW, panelists estimated that $73 \%$ were female, $20 \%$ were under age 20 , and $79 \%$ were presenting for the first time. The estimated prevalence of AGW in Morocco was $1.6 \%-2.6 \%$ in women and $2.0 \%$ $5.3 \%$ in men.

\section{Diagnosis of AGW}

Departments treating patients with AGW most commonly included gynecology, obstetrics, and dermatology. Diagnostic tests given always or regularly to patients presenting with AGW were HBV serology, HCV serology, VDRL for syphilis, and ELISA for HIV (Table 2). Cervical

Table 1 Physician and practice characteristics

\begin{tabular}{ll}
\hline & $\mathbf{N}=\mathbf{9}$ \\
\hline Physician characteristics & \\
Age, median (range) years & $50(43-57)$ \\
Sex, $n(\%)$ & \\
$\quad$ Male & $6(67 \%)$ \\
$\quad$ Female & $3(33 \%)$ \\
Specialty, $n$ (\%) & \\
Gynecology/obstetrics & $5(56 \%)$ \\
$\quad$ Dermatology & $4(44 \%)$ \\
Years in specialty practice, median (IQR) & $20(13-24)$ \\
Practice characteristics & \\
Patients seen per month, median (IQR) & $240(200-250)$ \\
AGW patients seen per month, median (IQR) & $4(2-5)$ \\
Duration of care for patients with AGW, median (IQR) & $20(17-20)$ \\
years & \\
Distribution of AGW patients, median (IQR) percentage & \\
$\quad$ Male & $37(30-70)$ \\
Female & $70(30-99)$ \\
Aged <20 years & $20(14-25)$ \\
First presentation & $79(50-80)$ \\
\hline
\end{tabular}

AGW, anogenital warts; IQR, interquartile range

A The mean value was 6.4 , which was the number used in the calculation of annual national costs

${ }^{B}$ The distribution of male and female patients was re-queried in round 2 , with a result of $73 \%$ female and $27 \%$ male. This is the result reported in the text 
Table 2 Diagnostic tests given to patients with anogenital warts $^{\mathrm{A}}$

\begin{tabular}{lll}
\hline Test & Never or sometimes & $\begin{array}{l}\text { Regularly } \\
\text { or always }\end{array}$ \\
\hline HBV serology & - & $100 \%$ \\
HCV serology & - & $100 \%$ \\
VDRL test for syphilis & - & $100 \%$ \\
ELISA for HIV & - & $89 \%$ \\
Biopsy & $89 \%$ & - \\
PCR for HPV & $89 \%$ & - \\
Cervical cytology & $33 \%$ & $67 \%$ \\
Penescopy & $100 \%$ & - \\
Anoscopy & $100 \%$ & - \\
Other & $100 \%$ & - \\
\hline
\end{tabular}

HBV, hepatitis B virus; $\mathrm{HCV}$, hepatitis C virus; VDRL, Venereal Disease Research Laboratory; ELISA, enzyme-linked immunosorbent assay; HIV, human immunodeficiency virus; $\mathrm{PCR}$, polymerase chain reaction; HPV, human papillomavirus

${ }^{\text {A }}$ The percentage of physicians with the indicated answers is shown

Table 3 Diagnosis of anogenital warts

\begin{tabular}{lll}
\hline Test & Rank & $\begin{array}{l}\text { Average } \\
\text { number of } \\
\text { visits }\end{array}$ \\
\hline $\begin{array}{ll}\text { Women } \\
\quad \text { Simple observation }\end{array}$ & 1 & 1.2 \\
$\quad$ Vulvar colposcopy & 2 & 1.6 \\
$\quad$ Biopsy & 3 & 1.8 \\
Men & & 1 \\
$\quad$ Simple observation & 1 & - \\
Biopsy & - &
\end{tabular}

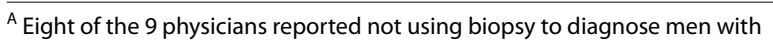
anogenital warts

cytology was reported as being used always or regularly by 6 out of 9 panelists (67\%). When asked to rank the procedures used to diagnose AGW, physicians ranked simple observation, vulvar colposcopy, and biopsy as first, second, and third, respectively, for women, while simple observation was universally used for men (Table 3 ). Women often required more than one visit to complete the diagnosis, whereas men usually required just one visit (Table 3). All panelists reported that a medical consultation is systematically conducted in the sexual partners of patients with AGW, with the same diagnostic procedures. Seven of the 9 panelists said that laboratory tests were systematically requested for the sexual partners.

\section{Availability of resources}

Eight of the 9 panelists reported that they have no available clinical practice guidelines for the treatment of
AGW at their institution, and for all 9, the main missing resource at their institution was pharmacological treatments.

\section{Treatment and follow-up}

Ablative therapy was reported by 8 of the 9 panelists as the primary first-line treatment. The primary reason for this was the lack of availability of pharmaceutical treatments. Among ablative treatments, excision was ranked \#1 by 6 of 8 respondents, and for most panelists (75\%), there was no alternative treatment (other choices were laser and cryotherapy). Excision required an estimated mean of 2 visits. The treatment choice was guided firstly by the number, size, and morphology of lesions; secondly by the cost; and thirdly by patient preference. When asked which kind of therapy is considered as the second line of treatment, excision was cited always or regularly by 5 of the 6 respondents (83\%). Among patients receiving ablative treatments, panelists reported that side effects arose sometimes (67\%) or regularly (33\%). Side effects included crust formation, burning, itching, and swelling. Only one panelist reported treating patients with pharmacological treatments and reported that the patients receiving pharmacological treatment sometimes had side effects, including itching, burning or swelling, and crust formation. All panelists reported that complications arose never or sometimes. Seven of the 9 panelists $(78 \%)$ declared that their patients with AGW were never hospitalized for more than $24 \mathrm{~h}$.

The consensus (89\%) was that 3 follow-up consultations were required per patient per year and that approximately $27 \%$ of patients treated for AGW had a recurrence. Recurrence was treated preferentially with excision $(67 \%$ always or regularly). Patients with recurrence were rarely referred to other specialties (100\% never or sometimes).

\section{Cost of AGW}

The estimated total costs of a case of AGW in women and men are shown in Table 4 . The cost estimates for women differed according to the diagnostic procedure used. The estimated cost of a case of AGW diagnosed by simple observation was $1442-1610$ MAD $(€ 137-153)$ in women and 1430-1590 MAD (€136-151) in men. The cost was lower in men than women because of the lower estimated number of visits required to obtain the diagnosis. Recurrence added 740-860 MAD (€70-82) to the expected costs in each case, giving totals of 2182-2470 MAD (€207-235) in women and 2170-2450 MAD $(€ 206-233)$ in men.

Based on the mean number of patient consultations reported by the panelists in this study (6.4 per month), the existence of 26 departments in Morocco (9 included in this study), and a $27 \%$ rate of recurrence, 
Table 4 Estimated total costs

\begin{tabular}{|c|c|c|c|c|}
\hline & \multicolumn{2}{|c|}{ Total cost without recurrence } & \multicolumn{2}{|c|}{ Total cost with recurrence } \\
\hline & MAD & Euros & MAD & Euros \\
\hline \multicolumn{5}{|l|}{ Women diagnosed by... } \\
\hline Simple observation & $1442-1610$ & 136.99-155.90 & $2182-2470$ & $207.29-237.60$ \\
\hline Vulvar colposcopy & $1530-1650$ & $145.35-156.75$ & $2270-2510$ & $215.65-238.45$ \\
\hline Biopsy & $1892-2012$ & 179.74-191.14 & $2632-2872$ & $250.04-272.84$ \\
\hline Men diagnosed by simple observation & $1430-1590$ & $135.85-151.05$ & $2170-2450$ & $206.15-232.75$ \\
\hline
\end{tabular}

Total cost without recurrence is the sum of (1) the cost of all diagnostic tests given regularly or always, (2) the final cost of the diagnostic method, (3) the cost of first-line treatment, and (4) the cost of follow-up via simple observation (see Supplementary Table S1). Simple observation had a range of costs, resulting in a range of estimated total costs. For total cost with recurrence, the cost of another round of treatment and follow-up was added to the initial cost estimate

MAD, Moroccan dirham

the total annual cost of medical consultations for AGW in Morocco ranged from 3,271,877 MAD to 4,253,703 $\operatorname{MAD}(€ 310,828-404,102)$.

\section{Discussion}

This study reports the methods of diagnosis and treatment of patients with AGW in Morocco, based on the consensus achieved among a panel of expert physicians. The panelists provided estimates of the monthly number of consultations for AGW and the number of visits needed to diagnose AGW. These data were used to calculate the costs associated with management of AGW in Morocco, both per case and nationally.

A systematic review by Raymakers et al. summarized what is currently known about the economic burden of AGW [6]. Included studies were from the United States, Europe, and Australia, as no published information was found in other regions. One publication from Spain is relevant here, based on geographical proximity to Morocco. Castellsague et al. used medical records from 2005 and several national cost databases to determine the HCRU and costs associated with AGW in Spain [21]. In this study, the mean number of physician visits for an episode of AGW in 2005 was 3.8. Approximately $75 \%$ of patients were prescribed medication for AGW at least once. The adjusted mean cost per patient was $€ 833$ from the Spanish National Health Service perspective, and the national annual cost was $€ 47$ million. These numbers are all quite different from those found in the current study: 6-7 visits per case ( 2 more for recurrence), rare to no use of prescription medication, and costs of $€ 206-273$ per patient and $€ 310,828-404,102$ nationally in Morocco.

Although differences in study designs and populations make it difficult to directly compare estimated costs, some general observations of Raymakers et al.
[6] may lend insight into the findings of the current study. The first was that, in almost all previous studies on the cost of AGW, including Castellsague et al. [21], costs were higher in women than in men, a finding with which our results agreed. Secondly, the main cost driver for AGW was physician visits, and a majority of previous studies reported that women had more visits than men, a trend consistent with our findings, and one that explains why costs are higher in women. Finally, in countries where both cervical cancer and AGW cost data are available (the United States and the United Kingdom), the national cost of AGW represents a significant proportion of the national cost of cervical cancer, suggesting that evaluations of the cost effectiveness of quadrivalent and nonavalent HPV vaccination should take not only cervical cancer but also AGW (and other HPV-related diseases) into account.

Most previous studies of HPV-related disease in Morocco have focused on cervical cancer [22-24]. Although according to GLOBOCAN 2018 data, Northern Africa has a low incidence of cervical cancer relative to other world regions [25], Morocco has the highest incidence and mortality rates among North African countries [26-28]. As of 2018, the age standardized incidence of cervical cancer is 17.2 per 100,000 women per year in Morocco (compared to 7.2 in Northern Africa and 13.1 worldwide), and the age-standardized mortality rate is 12.6 per 100,000 women per year (compared to 5.1 in Northern Africa and 6.9 worldwide) [26]. In part because of these regionally high rates, an economic analysis of countries in the extended Middle East and North Africa found that HPV vaccination would be cost effective in Morocco, up to a cost of $\$ 100$ (international dollars) per girl, in terms of cervical cancer cases avoided [29]. 
While cervical cancer is the primary focus of Morocco's planned HPV vaccination program, the prevention of AGW using the quadrivalent or nonavalent vaccine will provide additional benefits. In order for the full benefit of the HPV vaccination program to be realized, information on the epidemiological burden and cost of AGW is needed. This study is the first to provide such data.

The primary limitation of this study is that the data are based on expert opinion rather than objective and quantitative medical records or administrative databases. However, we note that previous studies of the HCRU and cost associated with AGW in other countries have used expert opinion (i.e., physician surveys) as a data source [21, 30-32]. Furthermore, the study includes a total of 9 physicians (4 dermatologists and 5 obstetricians/gynecologists). It is possible that the findings of the present study would have differed if physicians of other specialties were included. However, based on our investigations, most patients are referred to either a dermatologist or obstetrician so it is unlikely that including physicians of other specialties would change the outcomes of the study. Also, this analysis reflects patients treated only in the public sector, which almost certainly resulted in an underestimation of costs at the national level. The choice of ablative treatments to resolve AGW was determined for most of the panelists by the unavailability of pharmacological treatments. This is a limitation not only of this study, but of the Moroccan healthcare system, which is a resource-limited setting. For the cost of recurrence, it was assumed that the treatment and the number of follow-up visits were the same as for primary AGW, which may not always be the case. In previous studies, costs of recurrent or resistant cases were higher than for incident cases [6,21]. Likewise, national cost estimates assumed that physicians outside our panel used the same diagnosis and treatment strategies as our panel. Finally, this study did not estimate the indirect costs associated with days absent from work or disability caused by treatment of AGW. A lack of information on the indirect costs and humanistic burden of AGW characterizes the field as a whole [6] and should be the subject of future studies worldwide.

\section{Conclusions}

This study used expert consensus on diagnosis and treatment practices to demonstrate that AGW represent a burden to the Moroccan public healthcare system. These data are the first available on the management of AGW in Morocco and can inform policy decisions regarding this vaccine-preventable disease.

\section{Appendix: Questionnaire, Round 1}

\begin{tabular}{|c|c|c|}
\hline Section & Question & \\
\hline \multirow[t]{9}{*}{$\|$} & 1 & $\begin{array}{l}\text { In average, to how many do } \\
\text { you offer care per month? }\end{array}$ \\
\hline & 1 & $\begin{array}{l}\text { In average, to how many } \\
\text { patients with anogenital warts } \\
\text { do you offer care per month? }\end{array}$ \\
\hline & 2 & $\begin{array}{l}\text { Time offering care to patients } \\
\text { with anogenital warts: (years) }\end{array}$ \\
\hline & 3 & $\begin{array}{l}\text { From your patients with ano- } \\
\text { genital warts, what percent- } \\
\text { age are: (a) male, (b) female? }\end{array}$ \\
\hline & 4 & $\begin{array}{l}\text { From your patients with ano- } \\
\text { genital warts, what percent- } \\
\text { age is younger than } 20 \text { years } \\
\text { of age? }\end{array}$ \\
\hline & 5 & $\begin{array}{l}\text { From your patients with ano- } \\
\text { genital warts, what percent- } \\
\text { age presents the condition for } \\
\text { the first time? }\end{array}$ \\
\hline & 6 & $\begin{array}{l}\text { From your patients with ano- } \\
\text { genital warts for the first time, } \\
\text { what percentage are: (a) male, } \\
\text { (b) female }\end{array}$ \\
\hline & 7 & $\begin{array}{l}\text { From your patients with ano- } \\
\text { genital warts for the first time, } \\
\text { what percentage is younger } \\
\text { than } 20 \text { years of age? }\end{array}$ \\
\hline & 8 & $\begin{array}{l}\text { In the United States, the } \\
\text { prevalence of anogenital } \\
\text { warts in men ranges between } \\
2 \text { and } 11 \% \text {, while in women, } \\
\text { ranges between } 1 \text { and } 3 \% \text {. } \\
\text { What do you consider to be } \\
\text { the prevalence of anogenital } \\
\text { warts in your institution? }\end{array}$ \\
\hline \multirow[t]{3}{*}{$\| \mathrm{A}$} & 9 & $\begin{array}{l}\text { At your institution, what } \\
\text { department(s) offers care } \\
\text { to patients with anogenital } \\
\text { warts? }\end{array}$ \\
\hline & 10 & $\begin{array}{l}\text { In addition to the clinical } \\
\text { review, how often does your } \\
\text { institution conduct diagnosis } \\
\text { tests to patients with anogeni- } \\
\text { tal warts? (never, sometimes, } \\
\text { regularly, always) }\end{array}$ \\
\hline & 11 & $\begin{array}{l}\text { How often the following } \\
\text { diagnosis tests are ordered } \\
\text { for patients with suspected } \\
\text { anogenital warts at your } \\
\text { institution? HBV serology, HCV } \\
\text { serology, ELISA for HIV, VDRL } \\
\text { for syphilis, biopsy, PCR for } \\
\text { HPV, cervical cytology, penes- } \\
\text { copy, anoscopy, other (never, } \\
\text { sometimes, regularly, always) }\end{array}$ \\
\hline
\end{tabular}




\begin{tabular}{|c|c|c|}
\hline Section & Question & \\
\hline & $12 \mathrm{~A}$ & $\begin{array}{l}\text { In women with anogenital } \\
\text { warts, what are the diagnosis } \\
\text { procedures used at your } \\
\text { institution and the average } \\
\text { number of visits for each pro- } \\
\text { cedure? (please classify from } \\
\text { the most commonly used to } \\
\text { the least) Vulvar colposcopy, } \\
\text { biopsy, simple observation, } \\
\text { other (specify) (rank of use [1 } \\
\text { for the most commonly used], } \\
\text { average number of visits) }\end{array}$ \\
\hline & $12 B$ & $\begin{array}{l}\text { In men with anogenital warts, } \\
\text { what are the diagnosis proce- } \\
\text { dures used at your institution } \\
\text { and the average number of } \\
\text { visits for each procedure? } \\
\text { (please classify from the most } \\
\text { commonly used to the least) } \\
\text { Biopsy, simple observation, } \\
\text { other (specify) (rank of use [1 } \\
\text { for the most commonly used], } \\
\text { average number of visits) }\end{array}$ \\
\hline & $13 \mathrm{~A}$ & $\begin{array}{l}\text { At your institution, is a revision } \\
\text { systematically conducted in } \\
\text { sexual partners of patients } \\
\text { with anogenital warts? (yes, } \\
\text { no) [if "NO"go to question } \\
\text { 15A] }\end{array}$ \\
\hline & $13 B$ & $\begin{array}{l}\text { If "YES", what are the diagnosis } \\
\text { procedures conducted and } \\
\text { the average number of visits } \\
\text { for each procedure? (please } \\
\text { classify from the most com- } \\
\text { monly used to the least) } \\
\text { Vulvar colposcopy, biopsy, } \\
\text { simple observation, other } \\
\text { (specify) (rank of use [1 for the } \\
\text { most commonly used], aver- } \\
\text { age number of visits) }\end{array}$ \\
\hline & $14 \mathrm{~A}$ & $\begin{array}{l}\text { At your institution, are } \\
\text { laboratory tests systemati- } \\
\text { cally requested from sexual } \\
\text { partners of patients with } \\
\text { anogenital warts? (yes, no) [if } \\
\text { "NO" go to question 16] }\end{array}$ \\
\hline & $14 \mathrm{~B}$ & $\begin{array}{l}\text { If "YES", what one(s) of the } \\
\text { following are the most com- } \\
\text { monly requested? (please } \\
\text { choose the } 3 \text { most commonly } \\
\text { requested and rank from } 1 \\
\text { (most requested) to } 3 \text { (less } \\
\text { requested)) HBV serology, HCV } \\
\text { serology, ELISA for HIV, VDRL } \\
\text { for syphilis, biopsy, PCR for } \\
\text { HPV, cervical cytology, penes- } \\
\text { copy, anoscopy, other }\end{array}$ \\
\hline$\| I B$ & 15 & $\begin{array}{l}\text { At your institution, are there } \\
\text { available clinical practice } \\
\text { guidelines for the treatment } \\
\text { of anogenital warts? (yes, no) } \\
\text { [if"NO"go to question 18] }\end{array}$ \\
\hline
\end{tabular}

\begin{tabular}{|c|c|c|}
\hline Section & Question & \\
\hline & $16 \mathrm{~A}$ & $\begin{array}{l}\text { Do you have all needed } \\
\text { resources for the treatment } \\
\text { of anogenital warts as per the } \\
\text { guidelines? (yes, no) [if "YES" } \\
\text { go to question 17] }\end{array}$ \\
\hline & $16 \mathrm{~B}$ & $\begin{array}{l}\text { If the answer is "no", what } \\
\text { resources are lacking? }\end{array}$ \\
\hline \multirow[t]{8}{*}{ IIIC } & 17 & $\begin{array}{l}\text { At your institution, how often } \\
\text { patients with anogenital } \\
\text { warts receive specific type of } \\
\text { treatment? (never sometimes, } \\
\text { regularly, always) }\end{array}$ \\
\hline & $18 \mathrm{~A}$ & $\begin{array}{l}\text { At your institution, which kind } \\
\text { of therapy is considered as } \\
\text { the first line of treatment for } \\
\text { anogenital warts? Pharmaco- } \\
\text { logical treatments, ablative } \\
\text { treatments }\end{array}$ \\
\hline & $18 \mathrm{~B}$ & Why? \\
\hline & $18 C$ & $\begin{array}{l}\text { For either Pharmacological } \\
\text { or Ablative, which treat- } \\
\text { ment is the most commonly } \\
\text { prescribed as the first line of } \\
\text { treatment at your institution, } \\
\text { and the average number of } \\
\text { visits for each? (please classify } \\
\text { from the most commonly } \\
\text { prescribed to the least) Phar- } \\
\text { macological: Trichloroacetic } \\
\text { acid, Podophyllin, Imiquimod, } \\
\text { Other. Ablative: Cryotherapy, } \\
\text { Excision, Laser surgery, other. } \\
\text { [Rank (1 for the most com- } \\
\text { monly prescribed). Average } \\
\text { number of visits] }\end{array}$ \\
\hline & $18 \mathrm{D}$ & $\begin{array}{l}\text { For which reason(s) this } \\
\text { choice is made at your institu- } \\
\text { tion? (please choose the } 3 \\
\text { principal reasons and rank } \\
\text { from } 1 \text { (most important) to } \\
3 \text { (less important)) Number, } \\
\text { size, site and morphology of } \\
\text { lesions, convenience, patient } \\
\text { preference, adverse effects, } \\
\text { treatment cost, provider } \\
\text { experience }\end{array}$ \\
\hline & 19 & $\begin{array}{l}\text { At your institution, which kind } \\
\text { of therapy is considered as the } \\
\text { second line of treatment for } \\
\text { anogenital warts? Podophyl- } \\
\text { lin, imiquimod, cryotherapy, } \\
\text { trichloroacetic acid, excision, } \\
\text { laser surgery, other. (never, } \\
\text { sometimes, regularly, always) }\end{array}$ \\
\hline & $20 \mathrm{~A}$ & $\begin{array}{l}\text { At your institution, how often } \\
\text { do patients with anogenital } \\
\text { warts get hospitalized more } \\
\text { than } 24 \text { h fortreatment? } \\
\text { (never sometimes, regularly, } \\
\text { always) }\end{array}$ \\
\hline & $20 B$ & $\begin{array}{l}\text { In average how many days do } \\
\text { patients with anogenital warts } \\
\text { remain in the hospital? (days) }\end{array}$ \\
\hline
\end{tabular}




\section{Section}

IV

Question

How often do patients treated for anogenital warts have side effects? (never sometimes, regularly, always)

Do patients treated for anogenital warts have the following side effects? Burning, itching, or swelling, crust formation, discoloration, others (never, sometimes, regularly, always)

Do patients treated for anogenital warts have complications? (never sometimes, regularly, always)

How often do patients treated for anogenital warts have the following complications? bleeding, infection, deformity, other (never, sometimes, regularly, always)

23A At your institution, how often patients with anogenital warts are referred to other specialties? (never sometimes, regularly, always)

Mention which specialties: surgery, gynecology, urology, infectiology, dermatology, psychology, psychiatry, otorhinolaryngology, other (never, sometimes, regularly, always) In average, how many followup consultations are given to patients with anogenital warts each year?

At your institution, how many patients treated for anogenital warts have recurrences

At your institution, are photos taken from patients with recurrences? (never, sometimes, regularly, always) At your institution, what therapies are considered for the treatment of patients with anogenital warts when they recur? podophyllin, imiquimod, cryotherapy, trichloroacetic acid, excision, laser surgery, other (never, sometimes, regularly, always)

26A At your institution, are patients who recur after treatment for anogenital warts referred to other specialties? (yes, no)

\begin{tabular}{ll}
\hline Section & Question \\
\hline $26 B$ & To which of the following \\
& specialties are patients with \\
& recurrences from anogenital \\
& warts referred to? Surgery, \\
& gynecology, urology, infectiol- \\
& ogy, dermatology, psychology, \\
& psychiatry, otorhinolaryngol- \\
& ogy, other (never, sometimes, \\
& regularly, always)
\end{tabular}

Section I of the questionnaire asked about physician characteristics.

\section{Abbreviations}

AGW: Anogenital warts; ELISA: Enzyme-linked immunosorbent assay; HBV: Hepatitis B virus; HCRU: Healthcare resource utilization; HCV: Hepatitis C virus; HIV: Human immunodeficiency virus; HPV: Human papillomavirus; IQR: Interquartile range; MAD: Moroccan dirham; PCR: Polymerase chain reaction; VDRL: Venereal Disease Research Laboratory.

\section{Supplementary Information}

The online version contains supplementary material available at https://doi. org/10.1186/s13027-021-00403-1.

Additional file 1. Table S1. Base costs for diagnosis, first-line treatment, follow-up, and recurrence ${ }^{A}$.

\section{Acknowledgements}

The authors would like to thank Pr Mernissi Fatima Zahra of the Department of Dermatology, Faculty of Medicine and Pharmacy Hassan II, Fez, Morocco, Pr Elkarroumi Mohamed of the Department of Gynecology - Obstetrics, University Hospital Ibn Rochd of Casablanca, Casablanca, Morocco, Pr Yassir Ait Benkaddour of the Department of Gynecology - Obstetrics, University Hospital Mohammed VI, Marrakech, Morocco, Pr Said Amal of the Department of Dermatology, University Hospital Mohammed VI, Marrakech, Morocco and Pr Omar Laghzaoui : Department of Gynecology - Obstetrics, Military Hospital Moulay Ismail, Meknes, Morocco for their contributions. The authors also thank Melissa Stauffer, PhD, in collaboration with ScribCo, for medical writing assistance.

\section{Authors' contributions}

$\mathrm{MB}$ and TN conceived the study and designed the questionnaires. SD, AM, $\mathrm{SC}, \mathrm{KG}$ participated as investigators and conducted the questionnaire for the acquisition of the data in their respective center. MB and TN collected data and performed data analysis in each center. MB, TN, RH, GB, SD, AM, SC, and $K G$ analyzed the data for all the centers. MB drafted the paper. TN, GB, RH, and $\mathrm{SD}$ critically revised the manuscript. All the authors read and approved the final manuscript.

\section{Funding}

This study was funded by Merck Sharp \& Dohme Corp., a subsidiary of Merck \& Co., Inc., Kenilworth, NJ, USA.

Availability of data and materials

All data generated or analyzed during this study are included in this published article and its supplementary information files.

\section{Declarations}

Ethics approval and consent to participate

The study protocol was approved by a national ethics committee, the Comité D’Ethique pour la Recherche Biomédicale (CERB). 


\section{Consent for publication \\ Not applicable.}

\section{Competing interests}

Myriam Berrada, Ryan Holl, Tidiane Ndao, and Goran Benčina are employees of subsidiaries of Merck \& Co., Inc., Kenilworth, NJ, USA and own stock in Merck \& Co., Inc., Kenilworth, NJ, USA. Siham Dikhaye, Abdelilah Melhouf, Soumiya Chiheb, and Khalid Guelzim received honoraria from Merck Sharp \& Dohme Corp., a subsidiary of Merck \& Co., Inc., Kenilworth, NJ.

\section{Author details}

${ }^{1}$ MSD, Casablanca, Morocco. ${ }^{2}$ MSD, Kriens, Switzerland. ${ }^{3}$ Center for Observational and Real-World Evidence, MSD, Madrid, Spain. ${ }^{4}$ Department of Dermatology, Mohammed VI University Hospital of Oujda, Oujda, Morocco. ${ }^{5}$ Laboratory of Epidemiology, Clinical Research and Public Health, Faculty of Medicine and Pharmacy, Mohammed the First University of Oujda, Oujda, Morocco. ${ }^{6}$ Department of Gynecology - Obstetrics, Faculty of Medicine and Pharmacy Hassan II, Sidi Mohamed Ben Abdellah University, Fez, Morocco. 'Department of Dermatology, University Hospital Ibn Rochd of Casablanca, Casablanca, Morocco. ${ }^{8}$ Department of Gynecology and Obstetrics, Military and Training Hospital Mohammed V, Rabat, Morocco.

Received: 21 July 2021 Accepted: 31 October 2021

Published online: 14 November 2021

\section{References}

1. Insinga RP, Dasbach EJ, Elbasha EH. Epidemiologic natural history and clinical management of Human Papillomavirus (HPV) Disease: a critical and systematic review of the literature in the development of an HPV dynamic transmission model. BMC Infect Dis. 2009;9:119. https://doi.org/ 10.1186/1471-2334-9-119.

2. Cheng $L$, Wang $Y$, Du J. Human papillomavirus vaccines: an updated review. Vaccines (Basel). 2020. https://doi.org/10.3390/vaccines8030391.

3. Ljubojevic S, Skerlev M. HPV-associated diseases. Clin Dermatol. 2014;32:227-34. https://doi.org/10.1016/j.clindermatol.2013.08.007.

4. Bruni L, Albero G, Serrano B, Mena M, Gómez D, Muñoz J, Bosch F, de Sanjosé S. Human Papillomavirus and Related Diseases in the World. Summary Report 17 June 2019. ICO/IARC Information Centre on HPV and Cancer (HPV Information Centre).

5. Serrano B, Brotons M, Bosch FX, Bruni L. Epidemiology and burden of HPV-related disease. Best Pract Res Clin Obstet Gynaecol. 2018;47:14-26. https://doi.org/10.1016/j.bpobgyn.2017.08.006

6. Raymakers AJ, Sadatsafavi M, Marra F, Marra CA. Economic and humanistic burden of external genital warts. Pharmacoeconomics. 2012;30:1-16. https://doi.org/10.2165/11591170-000000000-00000.

7. Lawrence S, Walzman M, Sheppard S, Natin D. The psychological impact caused by genital warts: has the Department of Health's choice of vaccination missed the opportunity to prevent such morbidity? Int J STD AIDS. 2009:20:696-700. https://doi.org/10.1258/ijsa.2009.009120

8. Patel H, Wagner M, Singhal P, Kothari S. Systematic review of the incidence and prevalence of genital warts. BMC Infect Dis. 2013;13:39. https://doi.org/10.1186/1471-2334-13-39.

9. De Vuyst H, Alemany L, Lacey C, Chibwesha CJ, Sahasrabuddhe V, Banura C, Denny L, Parham GP. The burden of human papillomavirus infections and related diseases in sub-saharan Africa. Vaccine. 2013:31(Suppl 5):F3246. https://doi.org/10.1016/j.vaccine.2012.07.092.

10. Latif AS. Sexually, transmitted disease in clinic patients in Salisbury, Zimbabwe. Br J Vener Dis. 1981;57:181-3. https://doi.org/10.1136/sti.57.3.181.

11. Low AJ, Clayton T, Konate I, Nagot N, Ouedraogo A, Huet C, DidelotRousseau MN, Segondy M, Van de Perre P, Mayaud P. Genital warts and infection with human immunodeficiency virus in high-risk women in Burkina Faso: a longitudinal study. BMC Infect Dis. 2011;11:20. https://doi. org/10.1186/1471-2334-11-20.

12. Dareng EO, Adebamowo SN, Famooto A, Olawande O, Odutola MK, Olaniyan Y, Offiong RA, Pharoah PP, Adebamowo CA. Prevalence and incidence of genital warts and cervical Human Papillomavirus infections in Nigerian women. BMC Infect Dis. 2019;19:27. https://doi.org/10.1186/ s12879-018-3582-y.
13. Ginindza TG, Stefan CD, Tsoka-Gwegweni JM, Dlamini X, Jolly PE, Weiderpass E, Broutet N, Sartorius B. Prevalence and risk factors associated with sexually transmitted infections (STIS) among women of reproductive age in Swaziland. Infect Agents Cancer. 2017;12:29. https://doi.org/10.1186/ s13027-017-0140-y.

14. Jumaan AO, Ghanem S, Taher J, Braikat M, Al Awaidy S, Dbaibo GS. Prospects and challenges in the introduction of human papillomavirus vaccines in the extended Middle East and North Africa region. Vaccine. 2013:31(Suppl 6):G58-64. https://doi.org/10.1016/j.vaccine.2012.06.097.

15. Selmouni F, Zidouh A, Belakhel L, Sauvaget C, Bennani M, Khazraji YC, Benider A, Wild CP, Bekkali R, Fadhil I, Sankaranarayanan R. Tackling cancer burden in low-income and middle-income countries: Morocco as an exemplar. Lancet Oncol. 2018;19:e93-101. https://doi.org/10.1016/S14702045(17)30727-1.

16. Obeid DA, Almatrrouk SA, Alfageeh MB, Al-Ahdal MNA, Alhamlan FS. Human papillomavirus epidemiology in populations with normal or abnormal cervical cytology or cervical cancer in the Middle East and North Africa: a systematic review and meta-analysis. J Infect Public Health. 2020;13:1304-13. https://doi.org/10.1016/j.jiph.2020.06.012.

17. Avella JR. Delphi panels: research design, procedures, advantages, and challenges. Int J Doctoral Stud. 2016;11:305-21. https://doi.org/10.28945/ 3561

18. Minister of Social Affairs. Order No. 221-98. January 29,1998. Rates for procedures and services rendered by hospitals in Morocco. Accessed

19. Minister of Health. Order No. 1796-03. July 21, 2005. Nomenclature of medical biology analysis in Morocco. https://www.cnss.ma/sites/default/ files/NABM-sc.pdf. Accessed 23 Apr 2021

20. Minister of Health. Order No. 177-06. January 27, 2006. Establishment of the general nomenclature of professionals in Morocco. http://smorl.ma/ pdfs/Nomenclatures.pdf. Accessed 23 Apr 2021

21. Castellsague $X$, Cohet C, Puig-Tintore LM, Acebes LO, Salinas J, San Martin $\mathrm{M}$, Breitscheidel L, Remy V. Epidemiology and cost of treatment of genital warts in Spain. Eur J Public Health. 2009;19:106-10. https://doi.org/10. 1093/eurpub/ckn127.

22. Berraho M, Amarti-Riffi A, El-Mzibri M, Bezad R, Benjaafar N, Benideer A, Matar N, Qmichou Z, Abda N, Attaleb M, Znati K, El Fatemi H, Bendahhou K, Obtel M, Filali Adib A, Mathoulin-Pelissier S, Nejjari C. HPV and cofactors for invasive cervical cancer in Morocco: a multicentre case-control study. BMC Cancer. 2017;17:435. https://doi.org/10.1186/s12885-017-3425-z.

23. Khair MM, Mzibri ME, Mhand RA, Benider A, Benchekroun N, Fahime EM, Benchekroun MN, Ennaji MM. Molecular detection and genotyping of human papillomavirus in cervical carcinoma biopsies in an area of high incidence of cancer from Moroccan women. J Med Virol. 2009;81:678-84. https://doi.org/10.1002/jmv.21279.

24. Meftah el khair M, Ait Mhand R, Mzibri ME, Ennaji MM. Risk factors of invasive cervical cancer in Morocco. Cell Mol Biol (Noisy-le-Grand, France). 2009:55 Suppl:Ol1175-1185.

25. Bray F, Ferlay J, Soerjomataram I, Siegel RL, Torre LA, Jemal A. Global cancer statistics 2018: GLOBOCAN estimates of incidence and mortality worldwide for 36 cancers in 185 countries. CA Cancer J Clin. 2018;68:394424. https://doi.org/10.3322/caac.21492.

26. Bruni L, Albero G, Serrano B, Mena M, Gómez D, Muñoz J, Bosch F, de Sanjosé S. Human Papillomavirus and Related Diseases in Morocco. Summary Report 17 June 2019. ICO/IARC Information Centre on HPV and Cancer (HPV Information Centre).

27. Hussein WM, Anwar WA, Attaleb M, Mazini L, Forsti A, Trimbitas RD, Khyatti M. A review of the infection-associated cancers in North African countries. Infect Agents Cancer. 2016;11:35. https://doi.org/10.1186/ s13027-016-0083-8

28. Forman D, de Martel C, Lacey CJ, Soerjomataram I, Lortet-Tieulent J, Bruni L, Vignat J, Ferlay J, Bray F, Plummer M, Franceschi S. Global burden of human papillomavirus and related diseases. Vaccine. 2012;30(Suppl 5):F12-23. https://doi.org/10.1016/j.vaccine.2012.07.055.

29. Kim JJ, Sharma M, O'Shea M, Sweet S, Diaz M, Sancho-Garnier H, Seoud M. Model-based impact and cost-effectiveness of cervical cancer prevention in the Extended Middle East and North Africa (EMENA). Vaccine. 2013;31(Suppl 6):G65-77. https://doi.org/10.1016/j.vaccine.2012.06.096.

30. Hillemanns P, Breugelmans JG, Gieseking F, Benard S, Lamure E, Littlewood KJ, Petry KU. Estimation of the incidence of genital warts and the cost of illness in Germany: a cross-sectional study. BMC Infect Dis. 2008;8:76. https://doi.org/10.1186/1471-2334-8-76. 
31. Buenconsejo L, Kothari-Talwar S, Yee K, Kulkarni A, Lara N, Roset M, Giuliano AR, Garland S. Estimating the burden of illness related to genital warts in the Philippines: a nationally representative cross-sectional study. Infect Agents Cancer. 2019;14:26. https://doi.org/10.1186/ s13027-019-0240-y.

32. Lee TS, Kothari-Talwar S, Singhal PK, Yee K, Kulkarni A, Lara N, Roset M, Giuliano AR, Garland SM, Ju W. A cross-sectional study estimating the burden of illness related to genital warts in South Korea. BMJ Open. 2017;7: e014217. https://doi.org/10.1136/bmjopen-2016-014217.

\section{Publisher's Note}

Springer Nature remains neutral with regard to jurisdictional claims in published maps and institutional affiliations.
Ready to submit your research? Choose BMC and benefit from:

- fast, convenient online submission

- thorough peer review by experienced researchers in your field

- rapid publication on acceptance

- support for research data, including large and complex data types

- gold Open Access which fosters wider collaboration and increased citations

- maximum visibility for your research: over 100M website views per year

At BMC, research is always in progress.

Learn more biomedcentral.com/submissions 